\title{
The Effect of ROE on the PBV of Toll Road, Airport, Port, and Sub-Sector Companies in the Indonesia Stock Exchange
}

\author{
Andy \\ Postgraduate Management - Pakuan University \\ SH, Hengky \\ Bina Darma University \\ E-mail: hengky_halim@binadarma.ac.id
}

Received: June 5, $2021 \quad$ Accepted: August 6, $2021 \quad$ Published: Oct. 1, 2021

doi:10.5296/jmr.v13i4.18477ＵRL: https://doi.org/10.5296/jmr.v13i4.18477

\begin{abstract}
This research has been conducting before and during the Covid 19 pandemic and aims to test the effect of the Return on Equity (ROE) to the Price Book Value (PBV) of toll road subsector's companies, airports, and the like on the Indonesian Stock Exchange (ISE) for 6 years in Indonesia. This type of research uses quantitative research and is equipped with verification with an explanatory survey method. The sampling method used a purposive. It took from five sample companies. Data analysis in this study used panel data regression with the results: The results of this study indicate that ROE has a strong effect on firm value.
\end{abstract}

Keywords: Return On Equity (ROE), Price Book Value (PBV). 


\section{Introduction}

Return on Equity (ROE) is very influential growth of Price Book Value. While, ROE is part of the profitability ratio. The ratio is the company's ability to generate profits at certain levels of sales, assets and share capital (Saha, 2021). In this case, the companies studied are the toll road, airport and a similar sub-sector companies listed on the Indonesia Stock Exchange (ISE). These companies play a role in the Indonesian economy. They are the lifeblood of economic activity. Generally, these business activities are to provide infrastructure for the means of transportation used in these activities.

Price Book Value (PBV) measured growth of company's values. PBV is a ratio that indicates the price of traded shares has overvalued (above) or undervalued (below) the book value of the shares. The higher this ratio, it means that the market trusts the company's prospects (Hasanah, Hadiantini, \& Kusumawardhani, 2021). PBV also shows how far a company is able to create firm value relative to the amount of invested capital. To find out a company that is performing well, the PBV ratio value generally reaches above one that indicate that the stock market values are greater than its book value. A high PBV reflects the level of prosperity of shareholders, where prosperity for shareholders is the main goal of the company (Miqdad \& Oktaviani, 2021). A company that has a PBV ratio that increases from year after year means that the company has succeeded in creating and increasing company values. The higher the PBV ratio means the higher a company has valued by investors compared. It more the funds that have been invested in the company. The following is the PBV of toll road, airport and a similar sub-sector companies listed on the Indonesia Stock Exchange (ISE). 
Table 1. PBV \& ROE of Toll Road, Airport, and Similar Companies on the ISE 2015-2020

\begin{tabular}{|c|c|c|c|c|}
\hline No & Company & Years & PBV(\%) & ROE(\%) \\
\hline \multirow[t]{6}{*}{1} & Cardig Aero Services (CASS) & 2015 & 422 & 52,57 \\
\hline & & 2016 & 256 & 37,28 \\
\hline & & 2017 & 240 & 40,44 \\
\hline & & 2018 & 165 & 23,77 \\
\hline & & 2019 & 136 & 11,4 \\
\hline & & 2020 & 107 & $-5,97$ \\
\hline \multirow[t]{6}{*}{2} & Citra Marga Nusaphala Persada (CMNP) & 2015 & 161 & 10,87 \\
\hline & & 2016 & 106 & 10,86 \\
\hline & & 2017 & 100 & 12,4 \\
\hline & & 2018 & 76 & 8,67 \\
\hline & & 2019 & 91 & 9,22 \\
\hline & & 2020 & 100 & 6,13 \\
\hline \multirow[t]{6}{*}{3} & Jasa Marga (JSMR) & 2015 & 287 & 10,67 \\
\hline & & 2016 & 226 & 11,04 \\
\hline & & 2017 & 253 & 11,4 \\
\hline & & 2018 & 165 & 8,9 \\
\hline & & 2019 & 169 & 8,99 \\
\hline & & 2020 & 139 & 0,87 \\
\hline \multirow[t]{6}{*}{4} & ICTSI Jasa Prima (KARW) & 2015 & -10 & 74,75 \\
\hline & & 2016 & -30 & $-6,39$ \\
\hline & & 2017 & -11 & $-7,11$ \\
\hline & & 2018 & -10 & $-2,07$ \\
\hline & & 2019 & $-7,9$ & -2 \\
\hline & & 2020 & $-8,7$ & 0 \\
\hline \multirow[t]{6}{*}{5} & Nusantara Infrastructure (META) & 2015 & 43 & 8,1 \\
\hline & & 2016 & 71 & 8,17 \\
\hline & & 2017 & 130 & 5,59 \\
\hline & & 2018 & 149 & 8,47 \\
\hline & & 2019 & 123 & 5,61 \\
\hline & & 2020 & 118 & 2,24 \\
\hline
\end{tabular}

Source: https://www.idx.co.id/ 
Table 2. PBV of Toll Road, Airport, and Similar Sub-Sector Companies on the ISE 2015-2020

\begin{tabular}{|r|r|}
\hline Tahun & $\begin{array}{l}\text { PBV } \\
(\%)\end{array}$ \\
\hline 2015 & 180.6 \\
\hline 2016 & 125.8 \\
\hline 2017 & 142.4 \\
\hline 2018 & 109 \\
\hline 2019 & 102.22 \\
\hline 2020 & 91.06 \\
\hline
\end{tabular}

Souce: www.idx.co.id (2021)

Table 1 and 2 above shown the PBV value of the toll road, airport, and similar sub-sector companies in ISE tends to decline and only increased in 2017 for several companies. ROE shows the value of profitability for ordinary shareholders as an indicator of company performance (Mohamed, Ahmed, Mehdi, \& Hussain, 2021; Owusu \& Alhassan, 2021). In addition, ROE is also a reflection of the company in generating high returns to shareholders, which in turn will have an impact on company's value. A high ROE value will provide a positive signal for investors to buy company shares, an increase in demand for these shares will increase the share price that will then have an impact on increasing PBV. This study aims to examine the effect of ROE on the Price Book Value (PBV) of toll road, airport, and similar sub-sector companies in ISE before and during the Covid 19 pandemic.

\section{Literature Review}

\section{Price Book Value (PBV)}

Investing in stock investment instruments, of course, requires in-depth knowledge of the world of stocks starting from many terms that exist on the world of stocks and optimizing investment of various strategies. However, this time we are not discussing strategies to optimize stock investment in another thing that is no less important is the term of the world of stocks. PBV referred commonly to as the ratio of price booking to value. PBV is a measure that functions to see about shares in a company can be expensive or cheap. The PBV value is the division of the price per share of the company by the book value.

This PBV value has used to assess. While, the price of shares offered by the company is an expensive or cheap stock price. Given the PBV value is above the value 1, it is certain that the stock price is expensive, and vice versa. Keep in mind, that a cheap share price is not a guarantee that will bring great profits to shareholders. It could be that this value is low (Carhuamaca-Flores, Almonacid-Carranza, Santillan-Zapata, Venegas-Rodriguez, \& Deza-Quispe, 2021).

The PBV can be calculating by using the formula (Ligocká \& Stavárek, 2019): 


\section{$\mathrm{PBV}=\frac{\text { Stock Price }}{\text { Book Value }}$}

Meanwhile, ROE is a ratio that shows the extent of company in managing their capital effectively. It shows the profitability of the business (Mohamed et al., 2021; Owusu \& Alhassan, 2021). ROE can be calculated by the formula (Pennacchi \& Santos, 2021):

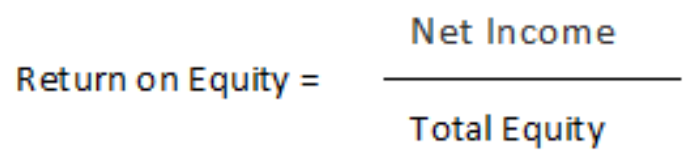

Framework: The Effect of ROE on PBV

ROE is one of the calculations included in the profitability ratio. ROE shows a company's ability to generate net profit using its own capital and generate net income available to owners or investors. ROE calculation can be using as a measure of the company's financial performance. ROE is dependent on the business. A small company had small capital relatively. So that, the resulting ROE is small, and plenty for large companies. ROE is an indicator of the amount of return on net income on equity and was expressing in percentage terms. ROE commonly uses to measure the ability of a business entity to generate profits with the equity that has been investing by shareholders (Schüürmann, Ebert, Chen, Wang, \& Kühne, 2008).

ROE shows the value of profitability for common shareholders as an indicator of company performance. In addition, ROE is also a reflection of the company in generating high returns to shareholders. A high ROE value will provide a positive signal for investors to buy it. This means that ROE can have a positive effect on PBV. This statement has supported by the results of research (Mohamed et al., 2021; Owusu \& Alhassan, 2021; Pennacchi \& Santos, 2021; Situm, 2021).

\section{$\mathrm{H}_{1}$ : ROE has a positive effect on PBV}

\section{Methodology}

The research location is the toll road companies, airports, and the like on the ISE. It carried out starting March 2021 that comes from financial data onto the ISE website. Methods and research to design. This type of research uses verification research with explanatory survey method used to test hypotheses (Canchy, Girardeau, Durand, Vouillac-Mendoza, \& Ahmed, 2021; Ongan, Isik, \& Ozdemir, 2020) and to explain phenomena in the form of relationships between variables. Research designed is a procedure that researchers use when selecting, collecting, and analyzing data as a whole. The study was conducting with the aim at examining the effect of ROE on the PBV of toll road, airport, and similar sub-sector companies on the ISE during the 2015-2020 period. Thus, the form of variable relationship of 
this study has causally related to the unit of analysis. The structural measurement of each variable uses a ratio to measure the scale.

The sample, researchers used purposive sampling (Ames, Glenton, \& Lewin, 2019; Barratt, Ferris, \& Lenton, 2015; Etikan, 2016) with research considerations. So that, future data collection is more representative (Han, Byun, Cho, \& Rim, 2021; Kao et al., 2021). The considerations for selecting the research sample are:

1) Samples of toll road, airport, and similar sub-sector companies listed on the Indonesia Stock Exchange

2) Sample of IPO companies $\geq 2015$

3) The sample period studied was from $2015-2020$

4) The sample of companies did not delist from the Indonesia Stock Exchange during the research

5) The sample companies have complete financial data onto $2015-2020$

Based on these criteria according to the sampling method used, there are 5 sample companies to be studied.

Research Variables (Cole, 2021; Zhang et al., 2021):

- Independent variable (X): ROE

- Dependent variable (variable Y): PBV

The data analysis technique uses panel data regression (Bernasconi, Wiest, Lavie, Milani, \& Laukkanen, 2021; Sparapani, Spanbauer, \& McCulloch, 2021) to determine the relationship between the ROE variable on the PBV of the toll road, airport, and similar sub-sectors on the ISE during the 2015-2020 period.

Data processing is using EViews 9 software. The goal is to test the significance of the independent - dependent variables (Cole, 2021; Zhang et al., 2021), it namely a Panel data. While, testing the hypothesis (Balsalobre-Lorente, Driha, Bekun, \& Adedoyin, 2020; Pata \& Caglar, 2021), this studied is using Panel data regression model (Bernasconi et al., 2021).

In addition, there are three methods of estimating the regression model using panel data, namely: random effects model based on data characteristics. To select the Panel data regression model, we used the Chow test (Eke, Eke, \& Inyang, 2016; Nielsen \& Whitby, 2015), Hausman test (Ahn \& Moon, 2014; Aït-Sahalia \& Xiu, 2019), and Lagrange multiplier test (Chen et al., 2021; Li \& Yao, 2021). The regression model (Bernasconi et al., 2021; Sparapani et al., 2021):

$$
\mathrm{PBV}_{\mathrm{it}}=\alpha+\beta_{1} \mathrm{ROE}_{\mathrm{it}}+\varepsilon_{\mathrm{it}}
$$




\section{Macrothink}

Where:

$$
\begin{aligned}
& \text { PBV }=\text { Price Book Value } \\
& \text { ROE }=\text { Return On Equity } \\
& \begin{array}{l}
\alpha \quad=\text { Constant } \\
\beta \quad=\text { the regression coefficient of each independent variable } \\
\qquad \quad=\text { Period = Error terms } \\
\mathrm{t} \quad=\text { Cross section company }
\end{array}
\end{aligned}
$$

Panel Data Regression Hypothesis Test:

Hypothesis testing is using the coefficient of determination (adjusted R2), F test, and T test with each probability less than 0.05 (Ongan et al., 2020).

\section{Result}

Model Development Results: The panel data model in this study uses a random effect model. The feature tested model selection of the research data characteristics. The model is suitable for use for this study. The following is the result of the regression analysis. 
Table 3. Regression Analysis

Dependent Variable: PBV

Method: Panel EGLS (Cross-section random effects)

Date: $03 / 22 / 21 \quad$ Time: $10: 31$

Sample: 20152020

Periods included: 6

Cross-sections included: 5

Total panel (balanced) observations: 30

Swamy and Arora estimator of component variances

\begin{tabular}{|c|c|c|c|c|}
\hline Variable & Coefficient & Std. Error & t-Statistic & Prob. \\
\hline $\mathrm{C}$ & 105.0004 & 42.19258 & 2.488599 & 0.0190 \\
\hline \multirow[t]{3}{*}{$\mathrm{ROE}$} & 1.659188 & 0.640338 & 2.591113 & 0.0150 \\
\hline & \multirow{2}{*}{\multicolumn{2}{|c|}{ Effects Specification }} & & \\
\hline & & & S.D. & Rho \\
\hline \multirow{2}{*}{\multicolumn{3}{|c|}{$\begin{array}{l}\text { Cross-section random } \\
\text { Idiosyncratic random }\end{array}$}} & 89.86086 & 0.7202 \\
\hline & & & 56.00885 & 0.2798 \\
\hline \multicolumn{5}{|c|}{ Weighted Statistics } \\
\hline R-squared & 0.195592 & \multirow{5}{*}{\multicolumn{2}{|c|}{$\begin{array}{l}\text { Mean dependent var } \\
\text { S.D. dependent var } \\
\text { Sum squared resid } \\
\text { Durbin-Watson stat }\end{array}$}} & 30.86897 \\
\hline Adjusted R-squared & 0.166863 & & & 60.93525 \\
\hline S.E. of regression & 55.61946 & & & 86618.70 \\
\hline F-statistic & 6.808203 & & & 0.762281 \\
\hline Prob(F-statistic) & 0.014401 & & & \\
\hline \multicolumn{5}{|c|}{ Unweighted Statistics } \\
\hline R-squared & 0.153092 & \multirow{2}{*}{\multicolumn{2}{|c|}{$\begin{array}{l}\text { Mean dependent var } \\
\text { Durbin-Watson stat }\end{array}$}} & 125.1800 \\
\hline Sum squared resid & 261243.3 & & & 0.252744 \\
\hline
\end{tabular}

Source: EViews Processing Results

Based on Table 3 above, the panel data regression-equation model in this study is:

$$
\mathrm{PBV}_{\text {it }}=105,0004+1,659188_{\text {it }} \mathrm{ROE}_{\text {it }}+\varepsilon_{\text {it }}
$$

The equation mentioned above can be explaining as follows:

a) $\mathrm{PBV}=$ Price Book Value

b) 105,0004 is the value of the coefficient $\alpha$ (constant)

c) 1,659188 is the value of the regression coefficient of ROE

d) $\varepsilon \quad=$ Error terms 
e) $\mathrm{t} \quad=$ Period of year $(2015-2020)$

f) $\mathrm{i} \quad=$ Cross section Company

\section{Hypothesis Test Results}

- Determination Coefficient Test (Adjusted $\mathrm{R}^{2}$ ) (Heo, Kho, Shin, Kim, \& Kim, 2008; Schüürmann et al., 2008):

This study found the Adjusted $\mathrm{R}^{2}$ value has a value of 0.166863 . This means that the independent variables in this study provide information on the prediction of variations in the dependent variable. It closed to one (1). In this case, PBV has influenced by ROE of $16.6863 \%$. The rest has influenced by other variables in this study $83.3137 \%$.

- F tests (Wang, 2008)

It has known that probability $\mathrm{F}$ statistical significance valued (0.01440). This means that ROE has a significant effect on PBV with a probability of $<0.05$.

- $\mathrm{T}$ tests (Kim, 2015; Sanderson \& Windmeijer, 2016)

- Testing the Effect of ROE on PBV

The initial hypothesis states that ROE has a positive effect on PBV. Based on the results of hypothesis testing, it has known that the probability of ROE is 0.0150 with a positive coefficient that indicates that the variable has a significant effect on PBV. The hypothesis is proven (reject $\mathrm{H}_{0}$ ).

\section{Discussion}

The Effect of ROE on PBV

Based on the results of the $\mathrm{T}$ test, the ROE variable has an influence on PBV. It has a probability value of 0.0150 and has a positive coefficient. This shows that the initial hypothesis that states that ROE has a positive effect on PBV has proven (Mohamed et al., 2021; Owusu \& Alhassan, 2021; Saha, 2021).

ROE shows the value of profitability for common shareholders as an indicator of company performance. In addition, ROE is also a reflection of the company in generating high returns to shareholders. A high ROE value will provide a positive signal for investors to buy it. The share will increase. It will have an impact on increasing PBV (Hasanah et al., 2021; Mohamed et al., 2021; Owusu \& Alhassan, 2021).

The PBV value of a company is often comparing with the value of other companies. This comparison aims to compare the expensive level of stock prices between companies. However, what needs to be considering in comparing the two values is to look at the similarity in the specifications of the two companies. Of course, investors must compare two companies with the same specifications. It is on a company scale, or from its movement sector. Such company specifications must be ensuring to be the same. They were different. Of course, an effective comparison could not be doing. 


\section{Conclusion}

Abovementioned the descriptions listed, it can be concluding that the PBV valued is highly correlated with ROE. This is an important measure in stock purchase decisions on investors. The PBV value determines that the stock price offered by the company is included in high or low price.

It should be note in relation to the PBV value that large-scale companies engaged in finance are very reasonable if they have a high PBV value. It is not detrimental to buy shares from large companies that have high PBV's values.

\section{Implication}

This pandemic distorted the correlation between ROE and PBV. Some small companies' growth is more resilient. The ROE movement does not follow the pattern of normal periods (non-pandemic). Even some large companies are experiencing ROE growth pressure (Table 2). The positive effect on ROE and PBV have not steady indicator for investors' purchasing decisions. They should also consider ROE patterns of this pandemic.

\section{References}

Ahn, S. C., \& Moon, H. R. (2014). Large-N and Large-T Properties of Panel Data Estimators and the Hausman Test. In Festschrift in Honor of Peter Schmidt (pp. 219-258). Springer New York. https://doi.org/10.1007/978-1-4899-8008-3_7

Ait-Sahalia, Y., \& Xiu, D. (2019). A Hausman test for the presence of market microstructure noise in high frequency data. Journal of Econometrics, 211(1), 176-205. https://doi.org/10.1016/j.jeconom.2018.12.013

Ames, H., Glenton, C., \& Lewin, S. (2019). Purposive sampling in a qualitative evidence synthesis: A worked example from a synthesis on parental perceptions of vaccination communication. BMC Medical Research Methodology, 19(1), 26. https://doi.org/10.1186/s12874-019-0665-4

Balsalobre-Lorente, D., Driha, O. M., Bekun, F. V., \& Adedoyin, F. F. (2020). The asymmetric impact of air transport on economic growth in Spain: fresh evidence from the tourism-led growth hypothesis. Current Issues in Tourism. https://doi.org/10.1080/13683500.2020.1720624

Barratt, M. J., Ferris, J. A., \& Lenton, S. (2015). Hidden Populations, Online Purposive Sampling, and External Validity. Field Methods, 27(1), 3-21. https://doi.org/10.1177/1525822X14526838

Bernasconi, A. A., Wiest, M. M., Lavie, C. J., Milani, R. V., \& Laukkanen, J. A. (2021). Effect of Omega-3 Dosage on Cardiovascular Outcomes: An Updated Meta-Analysis and Meta-Regression of Interventional Trials. Mayo Clinic Proceedings, 96(2), 304-313. https://doi.org/10.1016/j.mayocp.2020.08.034

Canchy, L., Girardeau, P., Durand, A., Vouillac-Mendoza, C., \& Ahmed, S. H. (2021). 
Pharmacokinetics trumps pharmacodynamics during cocaine choice: a reconciliation with the dopamine hypothesis of addiction. Neuropsychopharmacology, 46(2), 288-296. https://doi.org/10.1038/s41386-020-0786-9

Carhuamaca-Flores, A., Almonacid-Carranza, V. M., Santillan-Zapata, N. A., Venegas-Rodriguez, P. B., \& Deza-Quispe, J. A. (2021). The effects of financial factors on peruvian mining companies share price. Accounting, 7(2), 373-380. https://doi.org/10.5267/j.ac.2020.11.015

Chen, S., Chen, H., Mitsume, N., Morita, N., Bui, T. Q., Gao, W., \& Yoshimura, S. (2021). A nodal-based Lagrange multiplier/cohesive zone approach for dynamic interfacial cracking analysis of thin-walled laminated composite structures. Composite Structures, 256, 113112. https://doi.org/10.1016/j.compstruct.2020.113112

Cole, G. (2021). Sampling on the Dependent Variable: An Achille's Heel of Research on Displacement? Journal of Refugee Studies. https://doi.org/10.1093/jrs/feaa123

Eke, F. A., Eke, I. C., \& Inyang, O. G. (2016). Interest rate and commercial banks' lending operations in Nigeria: A structural break analysis using chow test. Global Journal of Social Sciences, 14(1), 9. https://doi.org/10.4314/gjss.v14i1.2

Etikan, I. (2016). A Comparison of Convenience Sampling and Purposive Sampling ProQuest. $\quad$ Retrieved March 29, 2021, from https://search.proquest.com/openview/56f5d21e88d7b1 f484434edd4b42f210/1?pq-origsite=g scholar\&cbl $=866377$

Han, M. S., Byun, J. H., Cho, Y., \& Rim, J. H. (2021, February 1). RT-PCR for SARS-CoV-2: quantitative versus qualitative. The Lancet Infectious Diseases. Lancet Publishing Group. https://doi.org/10.1016/S1473-3099(20)30424-2

Hasanah, S. F. N., Hadiantini, R., \& Kusumawardhani, A. P. (2021). Analysis of Macroeconomic Factors and Fundamental Factors to Sharia Stock Return on Trade, Services and Investment Sector Companies in Jakarta Islamic Index (JII) Period 2014-2018 (pp. 129-140). Atlantis Press. https://doi.org/10.2991/assehr.k.210312.020

Heo, J. H., Kho, Y. W., Shin, H., Kim, S., \& Kim, T. (2008). Regression equations of probability plot correlation coefficient test statistics from several probability distributions. Journal of Hydrology, 355(1-4), 1-15. https://doi.org/10.1016/j.jhydrol.2008.01.027

Kao, C.-F., He, S.-S., Wang, C.-S., Lai, Z.-Y., Lin, D.-G., \& Chen, S. (2021). A Modified Roger's Distance Algorithm for Mixed Quantitative-Qualitative Phenotypes to Establish a Core Collection for Taiwanese Vegetable Soybeans. Frontiers in Plant Science, 11, 2143. https://doi.org/10.3389/fpls.2020.612106

Kim, T. K. (2015). T test as a parametric statistic. Korean Journal of Anesthesiology, 68(6), 540-546. https://doi.org/10.4097/kjae.2015.68.6.540

Li, Z., \& Yao, J. (2021). Extension of the Lagrange multiplier test for error cross-section independence to large panels with non normal errors. Retrieved from 
http://arxiv.org/abs/2103.06075

Ligocká, M., \& Stavárek, D. (2019). The Relationship Between Financial Ratios and the Stock Prices of Selected European Food Companies Listed on Stock Exchanges. Acta Universitatis Agriculturae et Silviculturae Mendelianae Brunensis, 67(1), 299-307. https://doi.org/10.11118/actaun201967010299

Miqdad, M., \& Oktaviani, S. A. (2021). The Contribution of Social Media Value to Company's Financial Performance: Empirical Evidence from Indonesia. Journal of Asian Finance, Economics and Business, 8(1), 305-315. https://doi.org/10.13106/jafeb.2021.vol8.no1.305

Mohamed, E. A., Ahmed, I. E., Mehdi, R., \& Hussain, H. (2021). Impact of corporate performance on stock price predictions in the UAE markets: Neuro-fuzzy model. Intelligent Systems in Accounting, Finance and Management, isaf.1484. https://doi.org/10.1002/isaf.1484

Nielsen, B., \& Whitby, A. (2015). A Joint Chow Test for Structural Instability. Econometrics, 3(1), 156-186. https://doi.org/10.3390/econometrics3010156

Ongan, S., Isik, C., \& Ozdemir, D. (2020). Economic growth and environmental degradation: evidence from the US case environmental Kuznets curve hypothesis with application of decomposition. Journal of Environmental Economics and Policy, 1-8. https://doi.org/10.1080/21606544.2020.1756419

Owusu, F. B., \& Alhassan, A. L. (2021). $<$ scp $>$ Asset-Liability $</$ scp $>$ Management and bank profitability: Statistical cost accounting analysis from an emerging market. International Journal of Finance \& Economics, 26(1), 1488-1502. https://doi.org/10.1002/ijfe.1860

Pata, U. K., \& Caglar, A. E. (2021). Investigating the EKC hypothesis with renewable energy consumption, human capital, globalization and trade openness for China: Evidence from augmented ARDL approach with a structural break. Energy, 216, 11922. https://doi.org/10.1016/j.energy.2020.119220

Pennacchi, G. G., \& Santos, J. A. C. (2021). Why do banks target ROE? Journal of Financial Stability, 54, 100856. https://doi.org/10.1016/j.jfs.2021.100856

Saha, A. (2021). The use of return on equity as a criterion for stock selection in the Indian equity markets. In Journal of Physics: Conference Series (Vol. 1784, p. 12012). IOP Publishing Ltd. https://doi.org/10.1088/1742-6596/1784/1/012012

Sanderson, E., \& Windmeijer, F. (2016). A weak instrument F-test in linear IV models with multiple endogenous variables. Journal of Econometrics, 190(2), 212-221. https://doi.org/10.1016/j.jeconom.2015.06.004

Schüürmann, G., Ebert, R. U., Chen, J., Wang, B., \& Kühne, R. (2008). External validation and prediction employing the predictive squared correlation coefficient - Test set activity mean vs training set activity mean. Journal of Chemical Information and Modeling, 48(11), 2140-2145. https://doi.org/10.1021/ci800253u 
Situm, M. (2021). Determination of expected cost of equity with the CAPM: Theoretical extension using the law of error propagation. Managerial and Decision Economics, 42(1), 77-84. https://doi.org/10.1002/mde.3214

Sparapani, R., Spanbauer, C., \& McCulloch, R. (2021). Nonparametric machine learning and efficient computation with bayesian additive regression trees: The bart $\mathrm{r}$ package. Journal of Statistical Software, 97(1), 1-66. https://doi.org/10.18637/jss.v097.i01

Wang, X. L. (2008). Penalized maximal F test for detecting undocumented mean shift without trend change. Journal of Atmospheric and Oceanic Technology, 25(3), 368-384. https://doi.org/10.1175/2007JTECHA982.1

Zhang, J., Zhang, Y., Zheng, Z., Chen, Z., Xu, B., \& Yu, S. (2021). Finite-size analysis of continuous variable source-independent quantum random number generation. Quantum Information Processing, 20(1), 1-16. https://doi.org/10.1007/s11128-020-02936-7 